\title{
Perbaikan Tanah Dasar Menggunakan Pre-Fabricated Vertical Drain Dengan Variasi Kedalaman Dan Perkuatan Lereng Dengan Turap Studi Kasus : Lapangan Penumpukan Peti Kemas, Pelabuhan Trisakti, Banjarmasin, Kalimantan Selatan
}

\author{
Dofran Winner, Noor Endah, Putu Tantri Kumalasari \\ Jurusan Teknik Sipil, Fakultas Teknik Sipil dan Perencanaan Institut Teknologi Sepuluh Nopember \\ J1. Raya ITS, Surabaya 60111 \\ E-mail: noormochtar@gmail.com,tantrigeoteknik@gmail.com
}

\begin{abstract}
Abstrak - Metode perbaikan tanah dasar menggunakan preloading yang dikombinasikan dengan Pre-fabricated Vertical Drain (PVD) dipilih untuk proyek pengembangan lapangan penumpukan peti kemas di Pelabuhan Trisakti, Banjarmasin, Kalimantan Selatan. Selama masa preloading, ternyata kelongsoran selebar 37 meter terjadi di area penumpukan. Diketahui bahwa kelongsoran terjadi saat preloading setinggi 4,0 meter. Agar lapangan penumpukan dapat beroperasi kembali, diperlukan perencanaan untuk perkuatan lereng dan untuk menghilangkan pemampatan tanah dasar di area lapangan penumpukan.

Perbaikan tanah dasar menggunakan preloading yang dikombinasikan dengan Pre-fabricated Vertical Drain (PVD) digunakan untuk Zona 3, 4, dan 5, dan perkuatan lereng dengan turap digunakan untuk Zona-1 dan Zona-2 yang merupakan bagian lereng dari lapangan penumpukan. Direncanakan PVD dipasang pada kedalaman yang berbeda: $1 / 3 H, 2 / 3 H$, dan $\mathrm{H}$ (H adalah ketebalan lapisan tanah lunak) untuk melihat kondisi yang menghasilkan biaya paling murah.

Dari hasil perencanaan yang dilakukan, diketahui bahwa turap yang digunakan adalah Corrugated Concrete sheet pile type W-600 A1000. Turap dipasang sedalam 18 meter di Zona1 dan sedalam 22 meter di Zona-2; selain itu, angker dipasang pada turap untuk meningkatkan kekakuan turap. Hasil perencanaan juga menunjukkan bahwa biaya yang paling ekonomis adalah PVD dipasang sampai $2 / 3 \mathrm{H}$ di Zona-3, dan tanpa PVD di Zona-4 dan Zona-5. Total biaya konstruksi adalah sebesar Rp 843.106.053,00 untuk Zona-1 dan Zona-2; Rp 9.446.530.597,00 untuk Zona-3; Rp 1.869.613.200,00 untuk Zona 4; dan Rp 3.577.392.000,00 untuk Zona 5.
\end{abstract}

Kata Kunci - Lapangan Penumpukan Peti Kemas, Prefabricated Vertical Drain (PVD), Preloading, Turap

\section{PENDAHULUAN}

$\mathrm{P}$ Elabuhan Trisakti merupakan pelabuhan terbesar dan tersibuk di Kalimantan yang berfungsi sebagai pintu gerbang arus keluar masuk barang ekspor-impor, maupun barang antar pulau dan negara. Pelabuhan ini memiliki terminal peti kemas, terminal penumpang, terminal curah kering, dan terminal general cargo. Pelabuhan Trisakti merupakan pelabuhan kelas IA dalam lingkungan PT Pelindo III.

Dengan berjalannya waktu, kebutuhan akan jasa pelabuhan semakin meningkat. Pada tahun 2013, PT Pelindo III merencanakan pengembangan dermaga dan container yard (lapangan penumpukan peti kemas)..
Proyek pengembangan dermaga dan container yard ini menggunakan metode pra-pembebanan (pre-loading) dan pemasangan drainase vertikal (vertical drain). Lapangan penumpukan peti kemas ini didesain untuk menerima beban peti kemas 20 kaki dengan berat 24,00 ton per peti kemas setinggi 4 susun; dan peti kemas 40 kaki dengan berat 30,48 ton per peti kemas setinggi 4 susun. Namun, kurang dari satu bulan setelah lapangan penumpukan digunakan, konstruksi mengalami pergeseran, penurunan, dan retak-retak.

Oleh karena permasalahan tersebut, maka dilakukan analisis ulang. Dari hasil analisis tersebut diketahui bahwa kerusakan yang terjadi di container yard, dikarenakan adanya timbunan setinggi 4,00 meter, dimana kondisi ini menyebabkan kelongsoran yang berakibat pada terjadinya kerusakan. Oleh karena itu, perbaikan tanah container yard harus segera dilakukan agar dapat segera difungsikan kembali.

\section{METODOLOGI}

Metode yang digunakan dalam perencanaan adalah sebagai berikut:

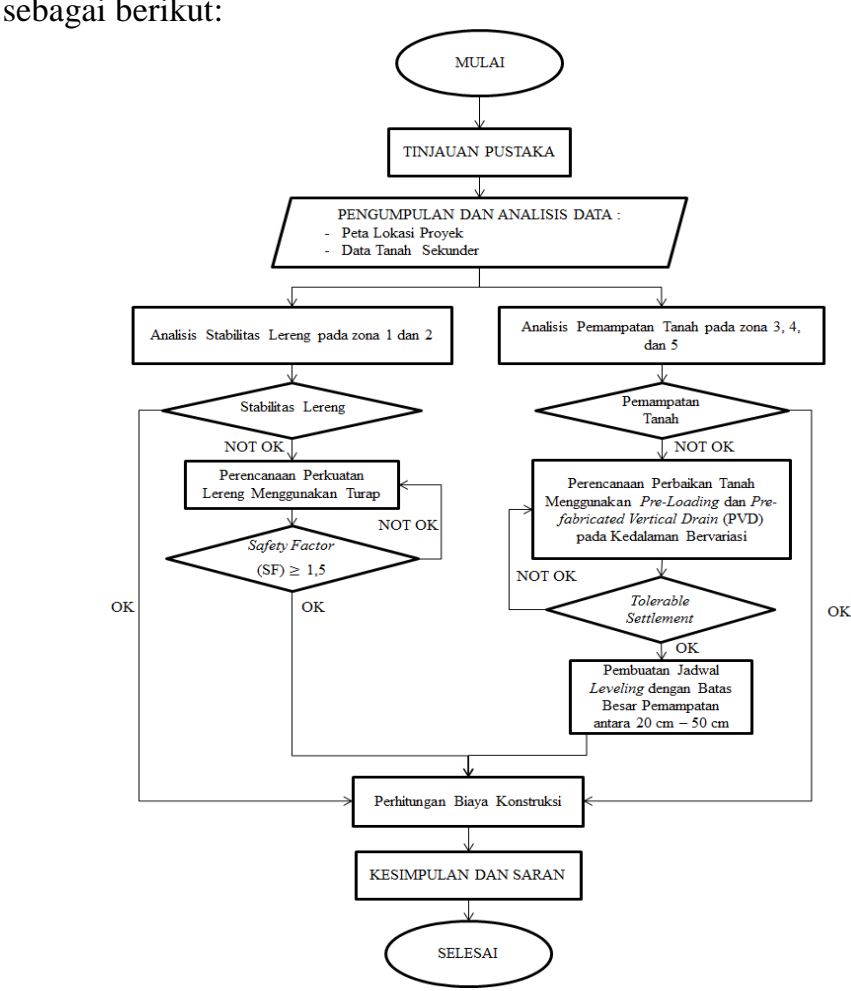

Gambar 1. Diagram Alir Metodologi Perencanaan 


\section{HASIL DAN PEMBAHASAN}

\section{A. Data dan Analisis}

\section{Data Tanah Dasar}

Data tanah yang digunakan dalam Penelitian ini adalah data borlog dan laboratorium dari laporan sementara hasil penyelidikan tanah pada area Penumpukan Petikemas Pelabuhan Trisakti Banjarmasin, Kalimantan Selatan. Data borlog yang tersedia merupakan hasil pekerjaan penyelidikan tanah Tahap I yang meliputi pemboran di 5 (lima) titik dengan kedalaman 50,0 $\mathrm{m}$ dan sondir sebanyak 4 (empat) titik. Sampel tanah asli (undisturbed sample) diambil dari 5 titik bor, yaitu BH-1, BH-2, BH-3, BH-4, dan $\mathrm{BH}-5$ pada kedalaman yang berbeda. Rekapitulasi data tanah pada setiap titik bor hasil analisis menggunakan metode statistik distribusi dan rumus korelasi, dapat dilihat pada buku Penelitian Penulis [1]. Berdasarkan hasil tersebut dapat dilihat bahwa tanah dasar memiliki perbedaan lapisan di setiap titik bor sehingga berdasarkan lokasi-lokasi titik bor tersebut, dilakukan zonifikasi yang ditunjukkan pada Gambar 2.

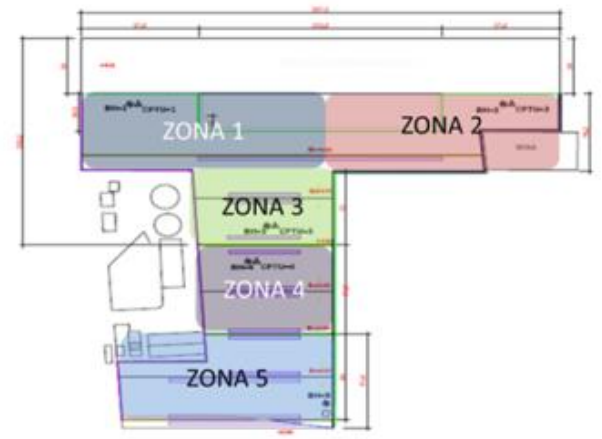

Gambar 2. Denah Zonifikasi

\section{Data Tanah Timbunan}

Spesifikasi teknis dari material timbunan adalah sebagai berikut:

- Sifat fisik tanah timbunan :

$$
\begin{array}{lc}
C=0 & \gamma_{\mathrm{t}}=1,85 \mathrm{t} / \mathrm{m}^{2} \\
\gamma_{\text {sat }}=1,85 \mathrm{t} / \mathrm{m}^{2} & \phi=30
\end{array}
$$

- Geometri Timbunan :

Tinggi tanah timbunan $\left(\mathrm{H}_{\text {final }}\right)$ direncanakan sebesar 1,40 $\mathrm{m}$ dari tanah dasar dengan luas area timbunan sebesar 32.000 $\mathrm{m}^{2}$.

\section{Data Beban}

Kondisi 1 (4 susun peti kemas 20 kaki) :

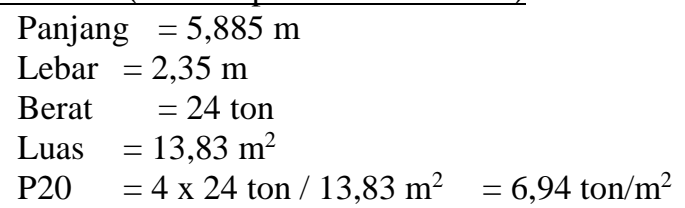

Kondisi 2 (4 susun peti kemas 40 kaki) :

$$
\begin{aligned}
& \text { Panjang }=12,033 \mathrm{~m} \\
& \text { Lebar }=2,35 \mathrm{~m} \\
& \text { Berat }=30,48 \mathrm{ton} \\
& \text { Luas }=28,28 \mathrm{~m}^{2} \\
& \mathrm{P} 40=4 \times 30,48 \text { ton } / 28,28 \mathrm{~m}^{2}=4,31 \text { ton } / \mathrm{m}^{2}
\end{aligned}
$$

Dari hasil perhitungan di atas, maka dipilih kondisi 1 karena menghasilkan beban terbesar. Setelah itu, menghitung beban dari rigid pavement setebal $25 \mathrm{~cm}$ :

$\mathrm{P}_{\text {slab }}=$ tebal rigid pavement $\mathrm{x} \gamma_{\text {beton }}$

$$
=0,25 \mathrm{~m} \times 2,4 \mathrm{ton} / \mathrm{m}^{3}=0,6 \mathrm{ton} / \mathrm{m}^{2}
$$

Maka, perhitungan beban total adalah sebagai berikut :

$$
\text { q } \mathrm{q}_{\text {beban }}=\mathrm{P} 20+\mathrm{P}_{\text {slab }}=7,54 \text { ton } / \mathrm{m}^{2}
$$

\section{Data Sheet Pile Beton}

Tipe sheet pile =Corrugated Type W-600 A1000

Section Modulus $=25530 \mathrm{~cm}^{3}$

Momen Inersia $\quad=765907 \mathrm{~cm}^{4}$

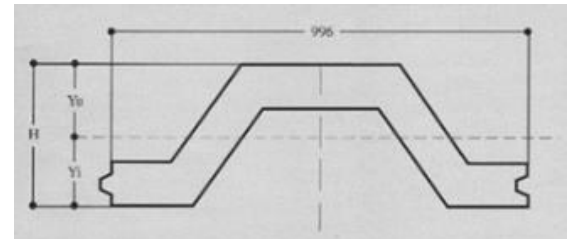

Gambar 3. Penampang Profil Sheet Pile Beton

\section{Data PVD}

Jenis PVD yang digunakan pada perencanaan ini adalah CeTeau Drain CT-D822 dari produksi PT. Teknindo Geosistem Unggul dengan spesifikasi sebagai berikut :

$$
\begin{aligned}
& \text { Weight }=75 \mathrm{~g} / \mathrm{m} \quad \text { Width (b) }=4 \mathrm{~mm} \\
& \text { Thickness }(\mathrm{a})=100 \mathrm{~mm}
\end{aligned}
$$

\section{B. Perencanaan Geoteknik}

Analisis Kelongsoran Talud Sebelum Perkuatan

Analisis kelongsoran talud sebelum perkuatan dilakukan untuk memeriksa nilai Safety Factor lereng akibat beban yang bekerja. Pemeriksaan dilakukan pada Zona 1, yang diwakili data tanah BH.1 dan Zona 2, yang diwakili data tanah BH.2. Analisis dilakukan dengan beban surcharge dari beban petikemas sebesar $7,54 \mathrm{t} / \mathrm{m}^{2}$. Nilai safety factor (SF) yang didapatkan dari analisis menggunakan program bantu Geoslope pada Zona 1 dan Zona 2 ditunjukkan pada Tabel 1. Tabel 1.

Nilai SF dan R Analisis Stabilitas Talud
\begin{tabular}{|c|r|r|}
\hline Zona & SF & \multicolumn{1}{|c|}{ R } \\
\hline \multirow{3}{*}{1} & 1.101 & 34.7 \\
& 1.103 & 28.467 \\
\hline \multirow{3}{*}{2} & 1.104 & 26.267 \\
\hline & 0.735 & 32.14 \\
& 0.766 & 31.84 \\
\hline
\end{tabular}

Dari hasil analisis diperoleh nilai SF untuk Zona 1 adalah diatas satu, sedangkan untuk Zona 2 adalah dibawah satu. Nilai SF Zona 1 walaupun sudah diatas satu, namun masih memiliki tingkat keamanan yang kecil. Oleh karena itu, kedua zona memerlukan perkuatan untuk dapat mencapai safety factor rencana yakni sebesar 1,5[2].

\section{Perencanaan Perkuatan Talud dengan Turap}

1. Perencanaan Turap tanpa Angker

Berikut tahapan dalam merencanakan turap tanpa angker:

1. Menentukan Asumsi Kedalaman Turap (do).

2. Nilai do pada BH.1 diasumsi di bawah kedalaman 18 $\mathrm{m}$, sedangkan pada BH.2 diasumsi di bawah kedalaman $16 \mathrm{~m}$.

3. Menghitung Tegangan Horizontal Aktif dan Pasif.

4. Mencari Nilai do.

Sketsa gaya-gaya yang bekerja pada turap ditunjukkan pada Gambar 4. Berdasarkan gaya-gaya tersebut, dilakukan perhitungan momen yang bekerja. Perhitungan tersebut dapat dilihat pada [1]. Perhitungan untuk mendapatkan persamaan momen $\Sigma \mathrm{M}=0$ ditunjukkan pada Tabel 2. Titik putar momen berada pada dasar turap. 


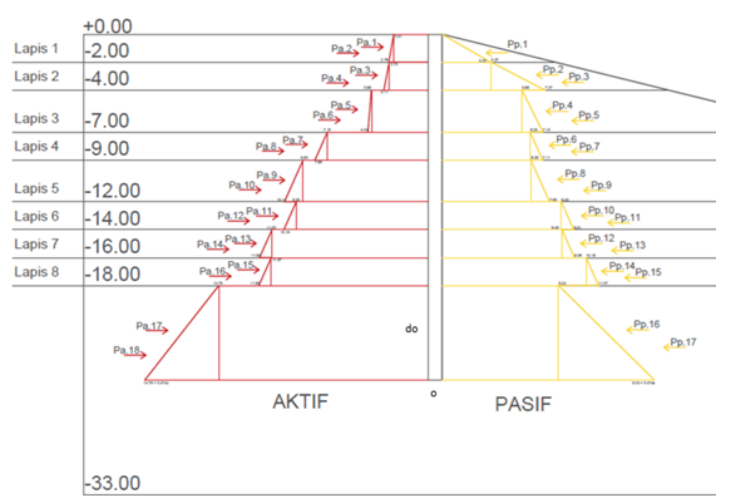

(a)

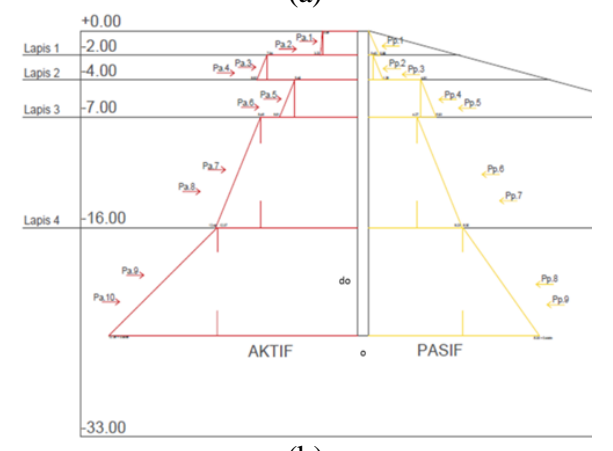

(b)

Gambar 4. Sketsa Gaya-gaya yang Bekerja: (a) BH.1; (b) BH.2

Tabel 2.

Perhitungan Persamaan Momen $\Sigma \mathrm{M}=0$ : (a) BH.1, (b) BH.2

(a)

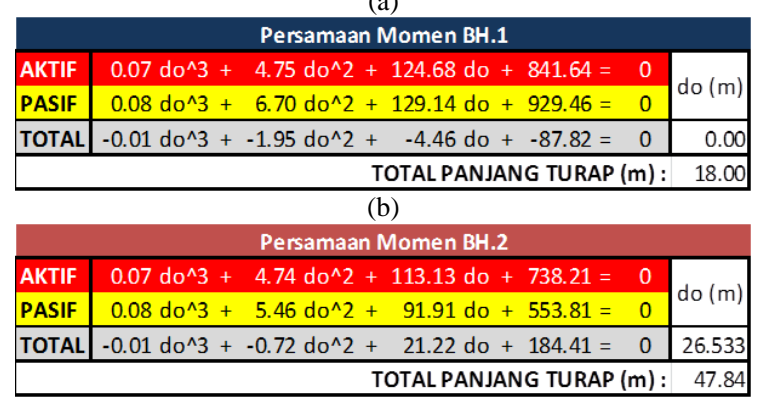

4. Menghitung Panjang Total Turap.

Setelah menghitung dengan pencarian faktor dari persamaan pangkat tiga, maka didapatkan nilai do untuk BH.1 adalah $0 \mathrm{~m}$, sedangkan untuk BH.2 adalah $26,533 \mathrm{~m}$. Nilai do ini kemudian dikalikan dengan angka keamanan, $\mathrm{SF}=1,2$ lalu dijumlahkan dengan tebal lapisan tanah di atasnya.

Sehingga total panjang turap yang dibutuhkan pada BH.1 adalah sebesar $18 \mathrm{~m}$, dan pada BH.2 adalah sebesar $47,84 \mathrm{~m} \approx 48 \mathrm{~m}$.

5. Menentukan Jumlah Turap yang akan Dipasang. Jumlah turap yang akan dipasang ditentukan dari perbandingan antara section modulus yang terjadi akibat momen yang bekerja pada turap dibandingkan dengan section modulus dari jenis turap yang digunakan. Dikarenakan section modulus turap Corrugated Type W-600 A1000 adalah sebesar 25530 $\mathrm{cm}^{3}$ dan lebih besar dari section modulus akibat momen yang bekerja pada turap, maka hanya dibutuhkan 1 buah turap tiap meter panjang melintang lereng.

Nilai do untuk BH.1 adalah $0 \mathrm{~m}$ diakibatkan gaya aktif yang bekerja pada turap lebih kecil dibandingkan dengan gaya pasif. Hal ini sesuai dengan analisis stabilitas lereng yang dilakukan sebelumnya bahwa nilai SF pada zona 1 lebih besar dari 1(satu). Namun, pemasangan turap tetap dilakukan dengan kedalaman $18 \mathrm{~m}$ untuk meningkatkan angka keamanan zona 1 .

\section{Perencanaan Turap Berangker}

Perencanaan turap berangker dilakukan hanya pada zona 2. Hal ini dilakukan untuk mengurangi panjang turap yang dibutuhkan karena kebutuhan panjang turap tanpa angker yakni sebesar $48 \mathrm{~m}$. Letak angker berada $1 \mathrm{~m}$ dibawah permukaan tanah dasar. Tahapan perhitungan turap berangker kurang lebih sama dengan perhitungan turap tanpa angker, namun yang membedakan adalah titik putar momen berada pada titik angker dipasang dan terdapat perhitungan dimensi angker. Perhitungan persamaan momen di BH.2 akibat angker ditunjukkan pada [1]. Dari hasil perhitungan diketahui total panjang turap adalah $22 \mathrm{~m}$.

1. Menentukan Diameter Baja Angker

Tabel 3 menunjukkan rekapitulasi gaya aktif dan pasif total, serta kuat tarik angker yang dibutuhkan. Tabel 3 .

Rekapitulasi Gaya Aktif, Pasif, dan Tarik Angker
\begin{tabular}{|l|r|}
$\Sigma$ Gaya Aktif (ton) & 159.934 \\
\hline$\sum$ Gaya Pasif (ton) & 145.9918 \\
\hline Gaya pada Angkur, T (ton) & 13.94216 \\
\hline
\end{tabular}

Direncanakan jarak antar angker 2 meter, maka:

$$
\begin{aligned}
& 2 \times \mathrm{T}=27,884 \mathrm{ton} \\
& \sigma \text { Angker }=1000 \mathrm{~kg} / \mathrm{cm}^{2} \\
& \sigma \text { Angker }=\frac{T}{A}=\frac{2 T}{0,25 \pi D^{2}} \\
& 1000=\frac{T}{A}=\frac{2 T}{0,25 \pi D^{2}} \\
& D=6 \mathrm{~cm}
\end{aligned}
$$

Maka diameter baja angker yang dibutuhkan adalah $6 \mathrm{~cm}$.

2. Merencanakan Blok Angker

Asumsi dimensi blok angker:

$\mathrm{H}=2 \mathrm{~m}$

$\mathrm{h}=1,5 \mathrm{~m}$

$\mathrm{K}_{\mathrm{o}}=0,4$

Menurut Teng (1962) apabila H/h $\leq 1,5$ maka tinggi blok angker (h) dapat dihitung sebagai $\mathrm{H}$.

Gaya yang bekerja pada blok angker dihitung sebagai berikut:

$$
\begin{aligned}
& P_{a}=1 / 2 H^{2} \gamma K_{a} \times 2=1 / 2 \times 2^{2} \times 1,20 \times 0,41 \times 2=1,948 t \\
& P_{p}=1 / 2 H^{2} \gamma K_{p} \times 2=1 / 2 \times 2^{2} \times 1,20 \times 2,46 \times 2=11,827 t
\end{aligned}
$$

Dengan Persamaan 2.48 pada [1], Tult $=1,5 \mathrm{x} \mathrm{T}$, lebar blok angker (B) dapat dihitung sebagai berikut:

$20,913 \leq B(11,827-1,948)+\frac{1}{3} \cdot 0,4 \cdot 1,20(\sqrt{2,46}+\sqrt{0,41}) \cdot 2^{3} \cdot \operatorname{tg} 30^{\circ}$

$\mathrm{B}=2 \mathrm{~m}$

3. Menghitung Panjang Baja Angker

Letak angker harus terletak pada daerah di belakang garis kelongsoran[4]. Dari sketsa skalatis letak blok angker, didapatkan panjang angker yang digunakan adalah $18 \mathrm{~m}$. Sketsa panjang angker ditunjukkan pada Gambar 5.

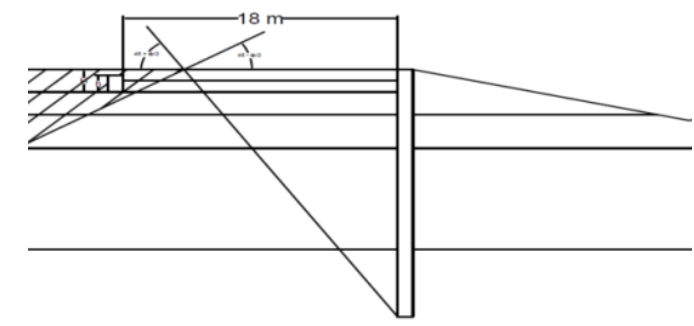

Gambar 5. Sketsa Panjang Angker

Analisis Kelongsoran Setelah Perkuatan 
Pemeriksaan dilakukan pada zona 1 setelah dipasang perkuatan turap tanpa angker sedalam $18 \mathrm{~m}$ dan pada zona 2 setelah dipasang perkuatan turap berangker sedalam $22 \mathrm{~m}$. Tabel 4 berikut ini adalah nilai safety factor (SF) yang didapatkan dari analisis menggunakan program bantu Geoslope pada Zona 1 dan Zona 2. Dari hasil analisis tersebut, diperoleh safety factor stabilitas lereng setelah menggunakan perkuatan pada kedua zona adalah $\geq 1,5$ Tabel 4.

Nilai SF dan R Analisis Stabilitas Setelah Perkuatan

\begin{tabular}{|c|r|r|}
\hline Zona & \multicolumn{1}{|c|}{ SF } & \multicolumn{1}{|c|}{ R } \\
\hline & 1.507 & 27.23 \\
1 & 1.531 & 26.15 \\
& 1.604 & 32.4 \\
\hline & 1.501 & 30.3 \\
2 & 1.504 & 31.76 \\
& 1.524 & 29.56 \\
\hline
\end{tabular}

\section{Perhitungan Timbunan Preloading}

Perhitungan preloading direncanakan pada Zona 3, 4, dan 5 yang data tanahnya masing-masing diwakili BH.3, BH.4, dan BH.5. Perencanaan ini memperhatikan pemampatan tanah akibat konsolidasi primer (primary consolidation) yaitu pada kondisi overconsolidated dengan pertimbangan kondisi tanah yang dipengaruhi oleh fluktuasi muka air laut. Tegangan akibat fluktuasi air sebesar $3 \mathrm{t} / \mathrm{m}^{2}$. Perhitungan tersebut memperoleh besar pemampatan (Sc), tinggi timbunan awal (H-Initial), dan tinggi timbunan akhir $(H$ Final) untuk perencanaan. Untuk mendapatkan nilai $H$ Initial dilakukan perhitungan pemampatan tanah dasar dengan variasi pemberian beban timbunan (q) [3], sedangkan $H$-Final diketahui setinggi 1,4 $\mathrm{m}$ dari permukaan tanah dasar. Perhitungan H-Initial dilakukan pada masing-masing alternatif kedalaman Pre-fabricated Vertical Drain (PVD) di setiap zona yaitu:

1. Alternatif panjang PVD penuh

2. Alternatif panjang PVD $2 / 3$ tanah lunak

3. Alternatif panjang PVD $1 / 3$ tanah lunak

4. Alternatif tanpa PVD

Variasi kedalaman PVD tersebut akan mengakibatkan tinggi $H$-Initial dan besar pemampatan yang berbeda pada masing-masing variasi. Perbedaan tersebut juga diakibatkan karena perbedaan besarnya tanah lunak yang akan memampat pada setiap zona. Berdasarkan data tanah, diperoleh lapisan mampu mampat $(\mathrm{N}-\mathrm{SPT} \leq 10)$ pada zona 3 sedalam $34 \mathrm{~m}$, zona 4 sedalam $35 \mathrm{~m}$, dan zona 5 sedalam 39 $\mathrm{m}$.

Perhitungan besar pemampatan (Sc) dilakukan terhadap hasil analisis data tanah. Pemampatan dihitung akibat variasi beban timbunan dan beban peti kemas. Perhitungan besar pemampatan dilakukan di tiga titik berbeda, yaitu di titik tengah timbunan, titik berjarak $10 \mathrm{~m}$ dari titik tengah timbunan, dan titik berjarak $15 \mathrm{~m}$ dari titik tengah timbunan. Perhitungan pada ketiga titik ini dilakukan untuk menghitung besarnya perbedaan pemampatan tanah dasar (differential settlement). Penjelasan lebih lanjut tentang differential settlement akan dijelaskan pada [1].

Cara perhitungan pemampatan pada alternatif kedalaman PVD yang lain sama seperti perhitungan pemampatan pada alternatif penuh, namun yang membedakan adalah besar lapisan tanah mampu mampat yang terlayani PVD. Perhitungan pemampatan dapat dilihat pada [1].

Setelah dilakukan perhitungan pemampatan, tinggi $H$ Initial dapat diperoleh dengan menggunakan (1):

$$
H_{\text {Initial }}=\frac{q_{\text {timbunan }}+S_{c} \times\left(\gamma_{\text {timb }}-\gamma^{\prime}{ }_{\text {timb }}\right)}{\gamma_{\text {timb }}}
$$

$\mathrm{H}_{\text {beban }}$ merupakan tinggi timbunan yang mewakili beban petikemas dan perkerasan. $\mathrm{H}_{\text {beban }}$, atau selanjutnya disebut $\mathrm{H}_{\text {bongkar, akan dibongkar setelah timbunan mengalami }}$ pemampatan sebesar yang direncanakan. Oleh karena itu persamaan $\mathrm{H}_{\text {final }}$ ditunjukkan pada (2):

$$
H_{\text {final }}=H_{\text {initial }}-H_{\text {bongkar }}-S_{c}
$$

Hubungan $H$-Initial dan $H$-Final, serta hubungan $H$-Final dan Sc kemudian dibuatkan grafik. Persamaan yang didapatkan dari grafik digunakan untuk menghitung $H$ Initial timbunan untuk mencapai H-Final 1,40 m dan untuk mencari besar pemampatan

Dengan cara yang sama diperoleh hasil perhitungan $H$ Initial dan Sc pada masing-masing variasi kedalaman di tiap titik bor. Rekapitulasi hasil perhitungan tersebut ditunjukkan pada Tabel 5.

Tabel 5.

Rekapitulasi H-Initial dan Sc: (a) BH.3; (b) BH.4; (c) BH.5 (a)

\begin{tabular}{|c|c|r|r|r|r|}
\hline Alternatif PVD & Kedalaman $(\mathrm{m})$ & H-Initial $(\mathrm{m})$ & H-Bongkar $(\mathrm{m})$ & H-Final $(\mathrm{m})$ & $\mathrm{Sc}(\mathrm{m})$ \\
\hline Penuh & 34 & 7.6 & 4.08 & 1.40 & 2.08 \\
\hline 2/3 Kedalaman & 23 & 6.7 & 4.08 & 1.40 & 1.26 \\
\hline 1/3 Kedalaman & 11 & 5.9 & 4.08 & 1.40 & 0.46 \\
\hline
\end{tabular}
Alternatif PVD Kedalaman (m) H-Initial (m) H-Bongkar (m) H-Final (m) Sc (m)

\begin{tabular}{|c|c|r|r|r|r|}
\hline Penuh & 35 & 7.7 & 4.08 & 1.40 & 2.26 \\
\hline 2/3 Kedalaman & 23 & 6.8 & 4.08 & 1.40 & 1.37 \\
\hline 1/3 Kedalaman & 12 & 6.1 & 4.08 & 1.40 & 0.64 \\
\hline
\end{tabular}

(c)

\begin{tabular}{|l|l|l|l|l|l|}
\hline Alternatif PVD & Kedalaman (m) & H-Initial (m) & H-Bongkar (m) & H-Final (m) & Sc (m) \\
\hline
\end{tabular}

\begin{tabular}{|c|c|r|r|r|r|}
\hline Penuh & 39 & 8.6 & 4.08 & 1.40 & 3.13 \\
\hline 2/3 Kedalaman & 26 & 7.7 & 4.08 & 1.40 & 2.27 \\
\hline 1/3 Kedalaman & 13 & 6.9 & 4.08 & 1.40 & 1.38 \\
\hline
\end{tabular}

\section{Perhitungan Waktu Pemampatan Tanpa PVD}

Setelah didapatkan besar pemampatan yang terjadi, dilakukan perhitungan waktu pemampatan. Perhitungan dilakukan untuk mengetahui perlu atau tidaknya untuk mempercepat waktu pemampatan.

Dari hasil perhitungan pada [1], dengan derajat konsolidasi (U) sebesar $90 \%$, waktu pemampatan pada zona 3 membutuhkan waktu selama 267,1985 tahun. Waktu pemampatan yang lama juga terjadi pada zona 4 dan zona 5 , yakni masing-masing selama 287,4894 tahun dan 377,117 tahun.

\section{Perencanaan PVD untuk Mempercepat Pemampatan}

Perencanaan PVD dilakukan pada masing-masing variasi kedalaman di masing-masing zona. Pilihan pola pemasangan yang dihitung adalah pola segitiga dan pola segiempat dengan variasi jarak antar titik PVD sebesar $0,8 \mathrm{~m} ; 1,0 \mathrm{~m}$; $1,2 \mathrm{~m} ; 1,4 \mathrm{~m} ; 1,6 \mathrm{~m} ; 1,8 \mathrm{~m}$; dan 2,0 m. Variasi jarak dilakukan untuk mendapatkan jarak pemasangan PVD yang efisien.

Rekapitulasi seluruh perhitungan dengan variasi jarak antar titik PVD dengan kedalaman bervariasi pada semua zona terdapat pada [1]. Dari perhitungan tersebut dihasilkan grafik hubungan $\bar{U}$ dengan waktu yang dibutuhkan untuk mencapai derajat konsolidasi yang direncanakan. Contoh grafik yang ditunjukkan pada Gambar 6 adalah hasil perhitungan pada zona 3 dengan alternatif PVD penuh. Dari grafik tersebut, dipilih pola pemasangan segitiga spasi 1,00 $\mathrm{m}$ dengan derajat konsolidasi sebesar $91 \%$ yang dicapai selama 25 minggu. Dengan cara yang sama pada perencanaan PVD 2/3 kedalaman, didapatkan derajat 
konsolidasi $90 \%$ yang dicapai selama 18 minggu (Gambar 7) dan pada perencanaan PVD 1/3 kedalaman, didapatkan derajat konsolidasi $91 \%$ yang dicapai selama 14 minggu (Gambar 8). Pola pemasangan ditetapkan menggunakan pola segitiga dengan spasi $1,00 \mathrm{~m}$ pada setiap variasi kedalaman di setiap zona untuk mempermudah perhitungan dan pelaksanaan.

\section{Perhitungan Differential Settlement}

Perhitungan differential settlement dilakukan untuk menghitung toleransi pemampatan (tolerable settlement, B) pada setiap variasi kedalaman PVD di tiap zona akibat perbedaan pemampatan di titik-titik yang telah ditentukan sebelumnya. Rekapitulasi besar pemampatan di tiap titik di bawah timbunan ditunjukkan pada Tabel 6 dan rekapitulasi perhitungan besar pemampatan di tiap titik dapat dilihat pada [1].

Nilai tolerable settlement dipengaruhi oleh jenis struktur di atas tanah dasar. Berdasarkan Tabel 2.5 pada [1], nilai tolerable settlement yang digunakan adalah sebesar 0,015. Nilai tolerable settlement pada tiap zona dihitung dengan menggunakan Persamaan 2.36 dari [1]. Rekapitulasi nilai tolerable settlement ditunjukkan pada Tabel 7.

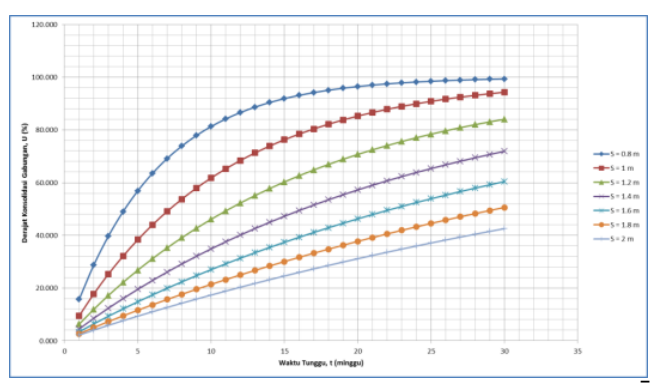

Gambar 6 Grafik Hubungan antara Derajat Konsolidasi (Ū) dan Waktu pada Alternatif PVD Penuh di BH.3

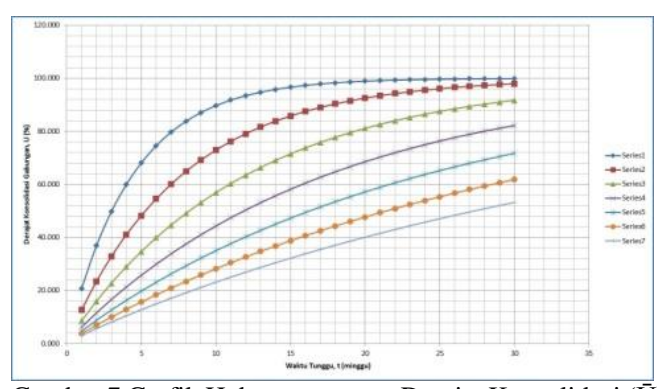

Gambar 7 Grafik Hubungan antara Derajat Konsolidasi (Ū) dan Waktu pada Alternatif PVD 2/3 Kedalaman di BH.3

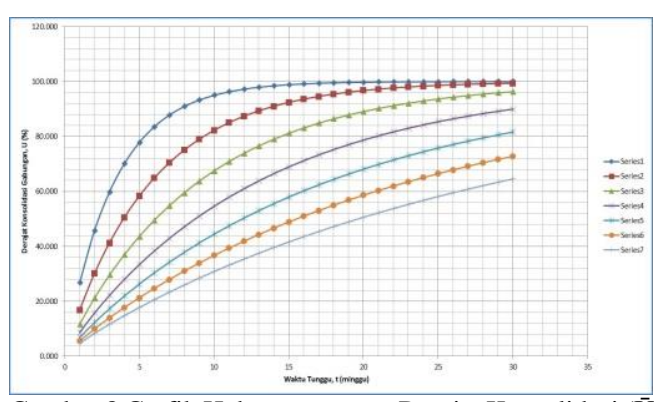

Gambar 8 Grafik Hubungan antara Derajat Konsolidasi (Ū) dan Waktu pada Alternatif PVD 1/3 Kedalaman di BH.3
Tabel 6.

Rekapitulasi Besar Pemampatan di Tiap Titik di Bawah Timbunan: (a) BH.3; (b) BH.4; (c) BH.5

\begin{tabular}{|c|c|c|c|c|c|c|c|}
\hline \multicolumn{8}{|c|}{ (a) } \\
\hline \begin{tabular}{|c|} 
Kedalaman \\
PVD (m)
\end{tabular} & \begin{tabular}{|c|} 
Lapisan di \\
Bawah PVD \\
(m)
\end{tabular} & $\mathrm{Sc}(\mathrm{m})$ & \begin{tabular}{|c|} 
Sisa \\
Pemampatan \\
(m)
\end{tabular} & $\begin{array}{c}\text { Sisa } \\
\text { Pemampatan } \\
\text { (m) }\end{array}$ & $\begin{array}{c}\text { Jarak antara } \\
\text { Tengah dan Titik } \\
10 \mathrm{~m}(\mathrm{~m})\end{array}$ & $\begin{array}{c}\text { Sc di Titik } 15 \mathrm{~m} \\
(\mathrm{~m})\end{array}$ & $\begin{array}{c}\text { Sisa } \\
\text { Pemampatan } \\
\text { (m) }\end{array}$ \\
\hline 34 & 0 & 2.08 & 0.00 & 0.00 & 10 & 1.82 & 0.00 \\
\hline 23 & 11 & 1.26 & 0.82 & 0.70 & 10 & 1.17 & 0.65 \\
\hline 11 & 23 & 0.46 & 1.63 & 1.46 & 10 & 0.44 & 1.37 \\
\hline 0 & 34 & 2.08 & 2.08 & 1.91 & 10 & 1.82 & 1.82 \\
\hline
\end{tabular}

\begin{tabular}{|r|r|r|r|r|r|r|r|}
\hline $\begin{array}{c}\text { Kedalaman } \\
\text { PVD }(\mathrm{m})\end{array}$ & $\begin{array}{c}\text { Lapisan di } \\
\text { Bawah PVD } \\
(\mathbf{m})\end{array}$ & Sc (m) & $\begin{array}{c}\text { Semampatan } \\
(\mathbf{m})\end{array}$ & $\begin{array}{c}\text { Sc di Titik 10 m } \\
(\mathbf{m})\end{array}$ & $\begin{array}{c}\text { Sisa } \\
\text { Pemampatan } \\
(\mathbf{m})\end{array}$ & $\begin{array}{c}\text { Sc di Titik 15 m } \\
(\mathbf{m})\end{array}$ & $\begin{array}{c}\text { Sisa } \\
\text { Pemampatan } \\
(\mathbf{m})\end{array}$ \\
\hline 35 & 0 & 2.26 & 0.00 & 2.16 & 0.00 & 2.11 & 0.00 \\
\hline 23 & 12 & 1.37 & 0.89 & 1.35 & 0.82 & 1.33 & 0.79 \\
\hline 12 & 23 & 0.64 & 1.62 & 0.64 & 1.53 & 0.63 & 1.48 \\
\hline 0 & 35 & 2.26 & 2.26 & 2.16 & 2.16 & 2.11 & 2.11 \\
\hline
\end{tabular}

(c)

\begin{tabular}{|r|r|r|r|r|r|r|r|}
\hline $\begin{array}{r}\text { Kedalaman } \\
\text { PVD }(\mathrm{m})\end{array}$ & $\begin{array}{c}\text { Lapisan di } \\
\text { Bawah PVD } \\
(\mathrm{m})\end{array}$ & $\mathbf{S c}(\mathrm{m})$ & $\begin{array}{c}\text { Sisa } \\
\text { Pemampatan } \\
(\mathrm{m})\end{array}$ & $\begin{array}{c}\text { Sc di Titik 10 m } \\
(\mathrm{m})\end{array}$ & $\begin{array}{c}\text { Sisa } \\
\text { Pemampatan } \\
(\mathrm{m})\end{array}$ & $\begin{array}{c}\text { Sc di Titik 15 m } \\
(\mathrm{m})\end{array}$ & $\begin{array}{c}\text { Sisa } \\
\text { Pemampatan } \\
(\mathrm{m})\end{array}$ \\
\hline 39 & 0 & 3.13 & 0.00 & 2.99 & 0.00 & 2.92 & 0.00 \\
\hline 26 & 13 & 2.27 & 0.86 & 2.22 & 0.77 & 2.19 & 0.73 \\
\hline 13 & 26 & 1.38 & 1.75 & 1.38 & 1.61 & 1.37 & 1.55 \\
\hline 0 & 39 & 3.13 & 3.13 & 2.99 & 2.99 & 2.92 & 2.92 \\
\hline
\end{tabular}

Tabel 7.

Rekapitulasi Nilai Tolerable Settlement tiap Variasi Kedalaman PVD : (a) Zona 3; (b) Zona 4; (c) Zona 5

\begin{tabular}{|c|c|c|c|}
\hline \multicolumn{4}{|c|}{ (a) } \\
\hline $\begin{array}{c}\text { Kedalaman } \\
\operatorname{PVD}(\mathrm{m})\end{array}$ & \begin{tabular}{|c|} 
Tolerable \\
Settlement \\
Titik $10 \mathrm{~m}, \boldsymbol{\beta}$
\end{tabular} & \begin{tabular}{|c|} 
Tolerable \\
Settlement \\
Titik $15 \mathrm{~m}, \boldsymbol{\beta}$
\end{tabular} & \\
\hline 34 & 0.0000 & 0.0000 & OK \\
\hline 23 & 0.0119 & 0.0116 & OK \\
\hline 11 & 0.0165 & 0.0168 & NOT OK \\
\hline 0 & 0.0175 & 0.0179 & NOTOK \\
\hline \multicolumn{4}{|c|}{ (b) } \\
\hline $\begin{array}{c}\text { Kedalaman } \\
\text { PVD (m) }\end{array}$ & \begin{tabular}{|c|} 
Tolerable \\
Settlement \\
Titik $10 \mathrm{~m}, \boldsymbol{\beta}$ \\
\end{tabular} & \begin{tabular}{|c|} 
Tolerable \\
Settlement \\
Titik $15 \mathrm{~m}, \boldsymbol{\beta}$
\end{tabular} & \\
\hline 35 & 0.0000 & 0.0000 & OK \\
\hline 23 & 0.0075 & 0.0071 & OK \\
\hline 12 & 0.0095 & 0.0094 & OK \\
\hline 0 & 0.0098 & 0.0099 & OK \\
\hline \multicolumn{4}{|c|}{ (c) } \\
\hline $\begin{array}{c}\text { Kedalaman } \\
\operatorname{PVD}(\mathrm{m})\end{array}$ & \begin{tabular}{|c|} 
Tolerable \\
Settlement \\
Titik $10 \mathrm{~m}, \boldsymbol{\beta}$
\end{tabular} & \begin{tabular}{|c|} 
Tolerable \\
Settlement \\
Titik $15 \mathrm{~m}, \boldsymbol{\beta}$ \\
\end{tabular} & \\
\hline 39 & 0.0000 & 0.0000 & OK \\
\hline 26 & 0.0096 & 0.0090 & OK \\
\hline 13 & 0.0134 & 0.0130 & OK \\
\hline 0 & 0.0140 & 0.0140 & OK \\
\hline
\end{tabular}

Berdasarkan hasil analisis tersebut, variasi PVD 1/3 kedalaman dan tanpa PVD pada zona 3 memiliki nilai tolerable settlement yang lebih besar dari 0,015 sehingga tidak dapat digunakan sebagai alternatif dalam perencanaan.

Perhitungan Overlay dan Penentuan Lama Waktu Overlay

Perhitungan overlay dilakukan pada alternatif PVD 2/3 kedalaman, PVD 1/3 kedalaman, dan alternatif tanpa PVD di setiap zona. Overlay (levelling) dilakukan karena pada ketiga alternatif perencanaan tersebut terdapat sisa pemampatan pada lapisan tanah lunak di bawah lapisan tanah yang terlayani PVD. Besar overlay ditentukan setinggi 30 $\mathrm{cm}$. Overlay dilakukan pada tiap tahun tertentu ketika pemampatan telah terjadi sebesar $0,3 \mathrm{~m}$. Besar pemampatan yang terjadi dapat diketahui dengan cara menghitung Rate of Settlement sehingga dapat diketahui waktu (dalam satuan tahun) diperlukannya overlay. Rekapitulasi waktu overlay pada setiap alternatif di setiap zona ditunjukkan pada Tabel 8. 


\section{Penimbunan Bertahap}

Penimbunan bertahap dilakukan untuk mempermudah metode pelaksanaan di lapangan. Pelaksanaan penimbunan bertahap dilakukan dengan menggunakan perencanaan kecepatan penimbunan $0,5 \mathrm{~m} / \mathrm{minggu}$. Dengan $H$-Initial yang didapatkan dari perhitungan sebelumnya, maka jumlah tahapan penimbunan berbeda-beda di tiap alternatif kedalaman PVD.

Perhitungan penimbunan bertahap dilakukan untuk mendapatkan nilai $\mathrm{Cu}$ baru. Nilai $\mathrm{U}$ yang digunakan untuk alternatif yang menggunakan PVD adalah menggunakan nilai $U$ akibat PVD yang direncanakan. Perhitungan dilakukan pada tiap lapisan tanah akibat tiap tahapan penimbunan. Rekapitulasi perhitungan penimbunan bertahap dan nilai $\mathrm{Cu}$ dapat dilihat pada [1].

\section{Perhitungan Biaya Material}

\section{Perhitungan Biaya Perkuatan Lereng}

Material yang digunakan dalam perkuatan lereng adalah beton precast sebagai material turap dan deadman angker, serta material baja untuk rod angker. Biaya tiap material adalah sebagai berikut:

- Beton precast per $\mathrm{m}^{3}=\mathrm{Rp} 820.000,00$

- Rod angker per kg = Rp 7.100,00

Dimensi perencanaan turap yang digunakan ditunjukkan pada Tabel 9. Rekapitulasi total biaya yang dibutuhkan di tiap zona ditunjukkan pada Tabel 10.

Tabel 9.

Dimensi Perencanaan Turap

\begin{tabular}{|l|r|}
\hline Luas Turap (cm2) & 2078 \\
\hline Luas Turap (m2) & 0.2078 \\
\hline Lebar Turap (m) & 0.996 \\
\hline Panjang Rod Angkur (m) & 18 \\
\hline Diameter Rod Angkur (m) & 0.06 \\
\hline Luas Blok Angkur (m2) & 3 \\
\hline Jarak antar Angkur (m) & 2 \\
\hline Berat Jenis Baja (kg/m3) & 7850 \\
\hline
\end{tabular}

Tabel 10.

Rekapitulasi Biaya Perkuatan Lereng

\begin{tabular}{|l|r|}
\hline \multicolumn{2}{|c|}{ ZONA 1 } \\
\hline Panjang Lereng $(\mathrm{m})$ & 97.5 \\
\hline Kedalaman Turap yang Dipasang $(\mathrm{m})$ & 18.00 \\
\hline Jumlah Turap yang Dipasang & 98 \\
\hline Biaya yang Dibutuhkan & Rp300,578,544.00 \\
\hline \multicolumn{2}{|c|}{ ZONA 2 } \\
\hline Panjang Lereng (m) & 97.5 \\
\hline Kedalaman Turap yang Dipasang (m) & 22.00 \\
\hline Jumlah Turap yang Dipasang & 98 \\
\hline Jumlah Angkur yang Dipasang & 49 \\
\hline Biaya yang Dibutuhkan & Rp542,527,509.91 \\
\hline Total Biaya Turap & Rp843,106,053.91 \\
\hline
\end{tabular}

\section{Perhitungan Biaya Alternatif Perbaikan Tanah Dasar}

Material yang digunakan dalam perbaikan tanah dasar adalah sirtu sebagai timbunan preloading dan overlay, serta PVD. Untuk ongkos pembongkaran antara lain adalah ongkos pindah petikemas dan ongkos bongkar pasang paving. Biaya material dan ongkos adalah sebagai berikut:

- Sirtu per $\mathrm{m}^{3}$

- PVD per $m$

$=\operatorname{Rp} 156.000,00$

- Ongkos pindah petikemas per peti $=\operatorname{Rp} 324.000,00$

- Ongkos bongkar pasang paving per $\mathrm{m}^{2}=\mathrm{Rp} 19.430,00$

Rekapitulasi biaya untuk timbunan preloading pada setiap alternatif di tiap zona, rekapitulasi biaya PVD dengan jarak pemasangan $1 \mathrm{~m}$, rekapitulasi biaya pembongkaran, dan rekapitulasi biaya overlay termasuk biaya pembongkaran di tiap tahun perencanaan overlay (Tabel 8) ditunjukkan pada [1]. Sedangkan rekapitulasi total biaya awal perencanaan ditunjukkan pada Tabel 11.

Tabel 11.

Rekapitulasi Total Biaya Awal Perencanaan

\begin{tabular}{|c|c|c|c|c|c|}
\hline Zona & Alternatif PVD & Kedalaman PVD (m) & Biaya Timbunan & Biaya PVD & Total Biaya Awal \\
\hline \multirow[b]{2}{*}{3} & \begin{tabular}{|l|} 
Penuh \\
\end{tabular} & 34 & $R p 8,278,826,849.28$ & Rp3,100,544,150.63 & Rp11,379,370,999.91 \\
\hline & $2 / 3$ Kedalaman & 23 & Rp 7,379,501,163.84 & Rp2,067,029,433.75 & Rpg,446,530,597.59 \\
\hline \multirow{4}{*}{4} & \begin{tabular}{|l|} 
Penuh \\
\end{tabular} & 35 & Rp10,335,248,478.36 & Rp3,892,145,496.28 & Rp14,227,393,974.64 \\
\hline & $2 / 3$ Kedalaman & 23 & Rp9,142,798,495.90 & \begin{tabular}{|l|l}
$R 22,594,763,664.18$ \\
\end{tabular} & Rp11,737,562,160.08 \\
\hline & $1 / 3$ Kedalaman & 12 & $\mathrm{Rp8}, 166,374,306.06$ & $\begin{array}{ll}61,297,381,832.09 \\
\end{array}$ & Rpg,463,756,138.11 \\
\hline & $\begin{array}{l}\text { Tanpa PVD } \\
\end{array}$ & & \begin{tabular}{|l|l|} 
Rp1,869,613,200.00 \\
\end{tabular} & Rp0.00 & Rp1, $869,613,200.00$ \\
\hline \multirow{4}{*}{5} & Penuh & 39 & \begin{tabular}{|l|l} 
Rp21,993,172,306.56 \\
\end{tabular} & \begin{tabular}{|l|l|}
$5 p 8,298,515,226.68$ \\
\end{tabular} & \begin{tabular}{|l|l} 
& $130,291,687,533.24$ \\
\end{tabular} \\
\hline & $2 / 3$ Kedalaman & 26 & Rp19,786,892,448.96 & \begin{tabular}{|l|l}
$\mathrm{Rp} 5,532,343,484,46$ \\
\end{tabular} & \begin{tabular}{|l|l}
$\mathrm{Rp} 25,319,235,933.42$ \\
\end{tabular} \\
\hline & $1 / 3$ Kedalaman & 13 & Rp17,530,907,284.80 & \begin{tabular}{|l|l}
$R 2,766,171,742.23$ \\
\end{tabular} & Rp20,297,079,027.03 \\
\hline & Tanpa PVD & & Rp3,577,392,000.00 & $\mathrm{Rp} 0.00$ & $\begin{array}{ll}\mathrm{pp} 3,577,392,000.00 \\
\end{array}$ \\
\hline
\end{tabular}

Berdasarkan rekapitulasi-rekapitulasi tersebut maka dapat diketahui bahwa perencanaan paling ekonomis adalah dengan alternatif PVD 2/3 kedalaman di zona 3 dengan biaya awal sebesar Rp 9.446.530.597,00; alternatif tanpa PVD di zona 4 dengan biaya awal Rp 1.869.613.200,00; dan alternatif tanpa PVD di zona 5 dengan biaya awal $\mathrm{Rp}$ 3.577.392.000,00.

Walaupun dengan alternatif tanpa PVD mengakibatkan waktu overlay yang lebih cepat, namun biaya yang dikeluarkan tidak sebesar dibandingkan dengan biaya menggunakan alternatif PVD di zona 4 dan zona 5. Alternatif tanpa PVD juga aman digunakan karena lapangan penumpukan telah mengalami perkuatan di lereng dengan turap. 
Tabel 8

Rekapitulasi Waktu Overlay pada Setiap Alternatif PVD di Setiap Zona

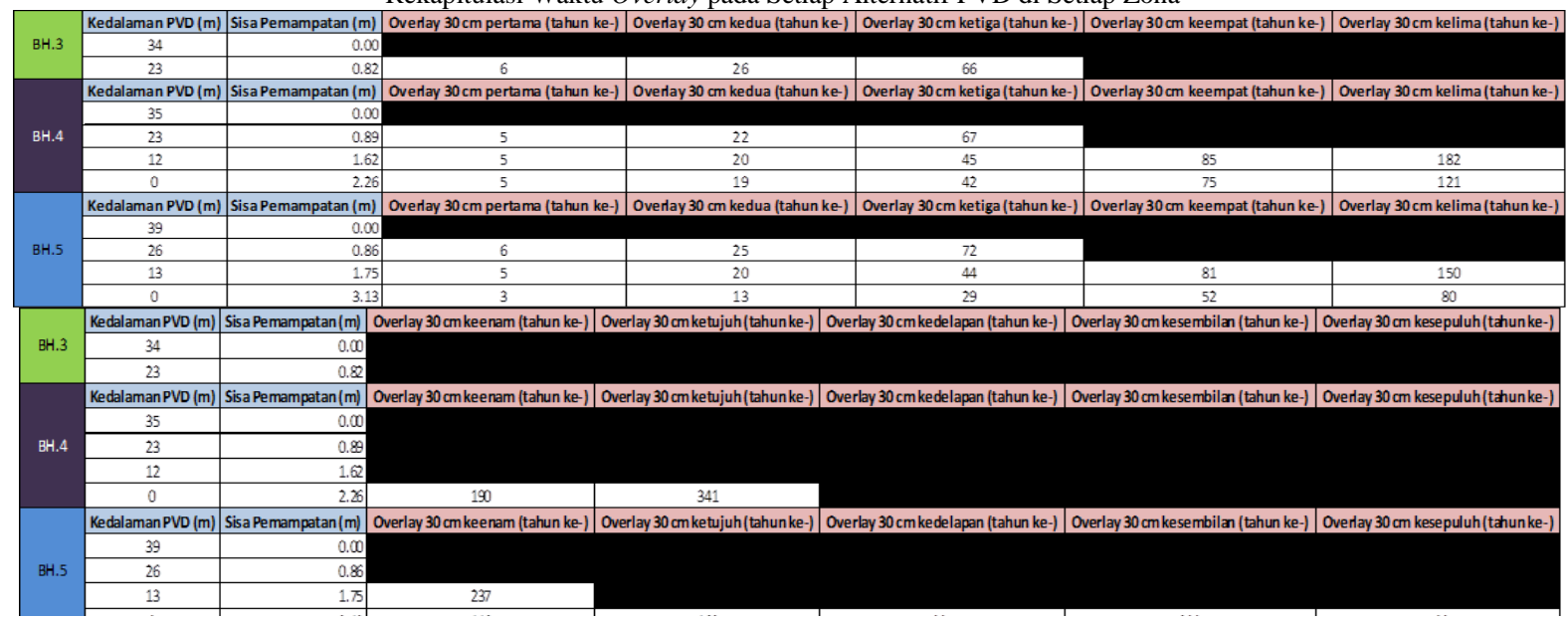

\section{PENUTUP}

\section{A. Kesimpulan}

Dari hasil perencanaan yang dilakukan dalam penelitian ini, didapatkan beberapa kesimpulan yaitu:

1. Ketebalan lapisan tanah lunak pada lokasi proyek adalah bervariasi yaitu 34.0 meter sampai dengan 39.0 meter.

2. Kedalaman PVD dan tinggi timbunan yang memberikan hasil perencanaan paling optimum dan ekonomis adalah: - Zona-3, kedalaman PVD 2/3 H (H=ketebalan lapisan tanah lunak) dan tinggi timbunan 6.70 meter;

- Zona-4 dan Zona-5, tidak perlu dipasang PVD dan tinggi timbunan 1.40 meter.

3. Jenis perkuatan lereng yang digunakan adalah turap beton Corrugated Type W-600 A1000 dengan section modulus $25530 \mathrm{~cm}^{3}$. Turap dipasang pada kedalaman yang berbeda yaitu 18.0 meter dan 22.0 meter, masing-masing di Zona-1 dan Zona-2. Turap di Zona-2 diperkuat dengan angker dimana jarak antar angker adalah 2.0 meter; angker ditarik dengan rod baja yang dikaitkan dengan blok angker dengan ukuran lebar $2.0 \mathrm{~m}$ dan tinggi $1,5 \mathrm{~m}$ yang diletakkan 18.0 meter dibelakang turap.

4. Total biaya pembangunan yang dibutuhkan pada Zona-1 dan Zona-2 adalah sebesar Rp 843.106.053,00; total biaya yang dibutuhkan pada Zona-3 adalah sebesar Rp 9.446.530.597,00; Zona-4 sebesar Rp 1.869.613.200,00; dan Zona-5 sebesar Rp 3.577.392.000,00.

\section{B. Saran}

Setelah dilakukan analisis dari hasil perencanaan yang telah dilakukan, beberapa hal perlu diperhatikan yaitu:

1. Konstruksi penahan tanah pada lereng yang menghadap ke sungai sangat diperlukan untuk melindungi lereng dari gerusan sungai.

2. Pemasangan angker yang berjarak $2.0 \mathrm{~m}$ dan lebar masing-masing blok angker yang juga $2.0 \mathrm{~m}$, maka blok angker dapat direncanakan sebagai balok menerus.

3. Perencanaan perkuatan lereng timbunan dengan jenis konstrusi lain seperti soldier pile atau retaining wall dikombinasi dengan tiang pancang perlu dipertimbangkan sebagai alternative perencanaan untuk menghindari pemasangan turap yang terlalu dalam.

\section{DAFTAR PUSTAKA}

[1]. Winner, Dofran. 2017. Perbaikan Tanah Dasar Menggunakan PreFabricated Vertical Drain dengan Variasi Kedalaman dan Perkuatan Lereng dengan Turap. Studi Kasus : Lapangan Penumpukan Peti
Kemas, Pelabuhan Trisakti, Banjarmasin, Kalimantan Selatan. Surabaya: Institut Teknologi Sepuluh Nopember (Belum dipublikasikan)

[2]. Das, Braja M. 1988. Mekanika Tanah: Prinsip-Prinsip Rekayasa Geoteknik jilid 2. Diterjemahkan oleh Noor Endah dan Indrasurya B.M. Surabaya: Erlangga.

[3]. Mochtar, Noor Endah. 2012. Modul Ajar Metode Perbaikan Tanah Surabaya: Jurusan Teknik Sipil FTSP-ITS.

[4]. Das, Braja M. 1990. Principles of Foundation Engineering. Boston: PWS-KENT 